\title{
Halomicrobium katesii sp. nov., an extremely halophilic archaeon
}

Correspondence

Mercedes Monteoliva-Sánchez mmonteol@ugr.es

\author{
Karima Kharroub, ${ }^{1,2}$ Catherine Lizama, ${ }^{1,3}$ Margarita Aguilera, ${ }^{1}$ \\ Abderrahmane Boulahrouf, ${ }^{4}$ Victoriano Campos, ${ }^{5}$ \\ Alberto Ramos-Cormenzana ${ }^{1}$ and Mercedes Monteoliva-Sánchez ${ }^{1}$
'Departamento de Microbiología, Facultad de Farmacia Campus de Cartuja s/n, 18071 Granada, Spain Constantine, Algeria
${ }^{3}$ Departamento de Tecnología Medica, Facultad de Ciencias de la Salud, Universidad de Antofagasta, Campus Coloso s/n, Antofagasta, Chile
${ }^{4}$ Institut des Sciences de la Nature Faculté des Sciences, Université Mentouri, Constantine, Algeria
${ }^{5}$ Laboratorio de Microbiología Ambiental, Universidad Católica de Valparaíso, Valparaíso, Chile \\ ${ }^{2}$ Institut de Nutrition de l'Alimentation et des Technologies Agro-Alimentaires, Université Mentouri,
}

Two extremely halophilic archaea, strains $\mathrm{Al}-5^{\top}$ and $\mathrm{K}-1$, were isolated from Lake Tebenquiche (Atacama Saltern, Chile) and Ezzemoul sabkha (Algeria), respectively. Cells of the two strains were short-rod-shaped and Gram-negative; colonies were orange-pigmented. They grew optimally at $37-40{ }^{\circ} \mathrm{C}$ and $\mathrm{pH} 7.0-7.5$ in the presence of $25 \%(\mathrm{w} / \mathrm{v}) \mathrm{NaCl}$. Magnesium was not required. Polar lipid analysis revealed the presence of phosphatidylglycerol and phosphatidylglycerophosphate methyl ester, the absence of phosphatidylglycerosulfate, and the presence of sulfated diglycosyl diether and diether diglycosyl as the sole glycolipids. DNA G+C contents of strains Al- $5^{\top}$ and $\mathrm{K}-1$ were 52.4 and 52.9 mol\% ( $T_{\mathrm{m}}$ method), respectively. 16S rRNA gene sequence comparison with database sequences showed that strains $\mathrm{Al}-5^{\top}$ and $\mathrm{K}-1$ were most closely related to Halomicrobium mukohataei DSM $12286^{\top}$ (similarities of 97.5 and $96.9 \%$, respectively). DNA-DNA hybridization indicated that strains $\mathrm{Al}-5^{\top}$ and $\mathrm{K}-1$ were members of a single species. However, DNA-DNA relatedness to Halomicrobium mukohataei was $55.7 \pm 2.5 \%$. A comparative analysis of phenotypic characteristics and DNA-DNA hybridization between the isolates and Halomicrobium mukohataei DSM $12286^{\top}$ supported the conclusion that $\mathrm{Al}-5^{\top}$ and $\mathrm{K}-1$ represent a novel species within the genus Halomicrobium, for which the name Halomicrobium katesii sp. nov. is proposed. The type strain is Al-5 ${ }^{\top}\left(=\right.$ CECT $7257^{\top}=$ DSM $\left.19301^{\top}\right)$.
The extremely halophilic archaea are found in hypersaline environments such as the Dead Sea, the Great Salt Lake, sabkhas and natural and artificial salterns. They are classified within the family Halobacteriaceae. Halobacteria are considered to be the most extremely halophilic microorganisms and require at least $1.5 \mathrm{M} \mathrm{NaCl}$ for their growth (Grant et al., 2001). Currently, members of the aerobic, extremely halophilic archaea are classified in 26 genera:

The GenBank/EMBL/DDBJ accession numbers for the $16 \mathrm{~S}$ rRNA gene sequences of isolates Al-5 $5^{\top}$ and K-1 are EF533994 and EU409597, respectively.

A phylogenetic tree, based on 16S rRNA gene sequences and constructed using the maximum-parsimony algorithm, of isolates $\mathrm{Al}-5^{\top}$ and $\mathrm{K}-1$ and related species is available with the online version of this paper.
Halobacterium (Grant, 2001a), Haloarcula and Haloferax (Torreblanca et al., 1986), Halobaculum (Oren et al., 1995), Halococcus (Grant, 2001b), Halogeometricum (MontalvoRodriguez et al., 1998), Halorubrum (McGenity \& Grant, 1995), Haloterrigena (Ventosa et al., 1999), Natrialba (Kamekura \& Dyall-Smith, 1995), Natrinema (McGenity et al., 1998), Natronobacterium and Natronococcus (Tindall et al., 1984), Natronomonas (Kamekura et al., 1997), Natronorubrum (Xu et al., 1999), Halomicrobium (Oren et al., 2002), Halorhabdus (Wainø et al., 2000), Halosimplex (Vreeland et al., 2002), Halobiforma (Hezayen et al., 2002), Halalkalicoccus (Xue et al., 2005), Natronolimnobius (Itoh et al., 2005), Halovivax and Halostagnicola (Castillo et al., 2006a, b), Haladaptatus (Savage et al., 2007), Haloquadratum (Burns et al., 2007), Halopiger (Gutiérrez et al., 2007) and Haloplanus (Bardavid et al., 2007). 
The genus Halomicrobium was proposed by Oren et al. (2002) and currently contains only one species, Halomicrobium mukohataei, which was first isolated from the soils of the Argentine salt flats (Ihara et al., 1997). In this study, the characterization of two halophilic strains that represent a novel species of the genus Halomicrobium is described.

Strain Al- $-5^{\mathrm{T}}$ was isolated from Lake Tebenquiche of the Atacama Saltern, Chile, and strain K-1 was isolated from water samples collected from Ezzemoul sabkha located in the north-east of Algeria. They were isolated independently from each other on hypersaline agar medium containing (per litre): $5 \mathrm{~g}$ proteose-peptone no. 5 (Difco), $5 \mathrm{~g}$ yeast extract (Difco), 1 g glucose with $25 \%$ (w/v) total salts. The stock of total salts at $30 \%(\mathrm{w} / \mathrm{v})$ was prepared as described by Subov (1931): $234 \mathrm{~g} \mathrm{NaCl}, 42 \mathrm{~g} \mathrm{MgCl}_{2} \cdot 6 \mathrm{H}_{2} \mathrm{O}, 60 \mathrm{~g}$ $\mathrm{MgSO}_{4} \cdot 7 \mathrm{H}_{2} \mathrm{O}, 1 \mathrm{~g} \mathrm{CaCl}_{2} \cdot 2 \mathrm{H}_{2} \mathrm{O}, 6 \mathrm{~g} \mathrm{KCl}, 0.2 \mathrm{~g} \mathrm{NaHCO}_{3}$, $0.7 \mathrm{~g} \mathrm{NaBr}, 0.005 \mathrm{~g} \mathrm{FeCl}_{3}$ and $1000 \mathrm{ml}$ distilled water. The medium was brought to $\mathrm{pH} 7.0$ and incubation was at $40{ }^{\circ} \mathrm{C}$. Phenotypic tests of strains $\mathrm{Al}-5^{\mathrm{T}}$ and $\mathrm{K}-1$ were performed according to the proposed minimal standards for the description of new taxa in the order Halobacteriales (Oren et al., 1997). Cell morphology was examined by transmission electron microscopy of exponentially growing cells in broth containing $25 \%(\mathrm{w} / \mathrm{v}) \mathrm{NaCl}$ and Gram staining was performed by using acetic-acid-fixed samples as described by Dussault (1955). Colony morphology was observed on solid medium after incubation at $40{ }^{\circ} \mathrm{C}$ for 5 days. The requirement for $\mathrm{NaCl}$ was determined in media containing $0-30 \%(\mathrm{w} / \mathrm{v}) \mathrm{NaCl}$. Tolerance to $\mathrm{pH}$ was tested in solid medium at $\mathrm{pH}$ 5.0, 6.0, 6.5, 7.0, 7.5, 8.0, 8.5, 9.0 and 10.0. The requirement for magnesium was tested in media containing final concentrations of $0.0,0.005,0.1$, $0.2,0.4,0.8$ and $3.2 \%(\mathrm{w} / \mathrm{v}) \mathrm{MgCl}_{2}$ at the optimum $\mathrm{NaCl}$ concentration for growth. The temperature range for growth was tested by incubating cultures on agar plates at $30-55{ }^{\circ} \mathrm{C}$. Reduction of nitrate was tested by using the sulfanilic acid and $\alpha$-naphthylamine reagent (Smibert \& Krieg, 1981). Anaerobic growth in the presence of $\mathrm{L}$ arginine and nitrate was tested as described by Oren $e t$ al. (1997). Controls without arginine and nitrate were included and incubation was performed in the dark. Catalase and oxidase activities were tested according to Gerhardt et al. (1994). Tests for formation of indole and hydrolysis of starch, gelatin and aesculin were as described previously (González et al., 1978). Hydrolysis of Tweens 20, 40, 60 and 80 was tested as outlined by Gutiérrez \& González (1972). Utilization of carbohydrates and other compounds as carbon sources and acid production from these compounds were determined as described by Oren et al. (1997). The determination of antibiotic susceptibility was performed by spreading bacterial suspensions on plates containing medium with $25 \%(\mathrm{w} / \mathrm{v}) \mathrm{NaCl}$ and applying antibiotic discs [penicillin G, $10 \mathrm{U}$; kanamycin, $30 \mathrm{mg}$; tetracycline, $30 \mathrm{mg}$; erythromycin, $15 \mathrm{mg}$; streptomycin, $10 \mathrm{mg}$; bacitracin, $10 \mathrm{U}$; novobiocin, $30 \mathrm{mg}$; polymyxin $\mathrm{B}$, $300 \mathrm{U}$; ampicillin, $10 \mathrm{mg}$; neomycin, $30 \mathrm{mg}$; chlor- amphenicol, $30 \mathrm{mg}$; gentamicin, $10 \mathrm{mg}$; and carbenicillin, $50 \mathrm{mg}$ (Lizama et al., 2001)].

Cells of strain $\mathrm{Al}-5^{\mathrm{T}}$ were non-motile, short-rod-shaped, $1.80-2.25 \times 2.25-2.80 \mu \mathrm{m}$ in size and both novel strains stained Gram-negative. Cell lysis occurred in distilled water. Colonies on standard growth agar medium were small and circular with entire margins and smooth surfaces. The two novel strains formed orange-coloured colonies about $2.0 \mathrm{~mm}$ in diameter after incubation for 5 days on the medium given above at $40{ }^{\circ} \mathrm{C}$.

Strains $\mathrm{Al}-5^{\mathrm{T}}$ and $\mathrm{K}-1$ grew in the presence of $\mathrm{NaCl}$ concentrations ranging from $20 \%(3.4 \mathrm{M})$ to $30 \%$ $(5.2 \mathrm{M})$. They grew optimally in the presence of $25 \%$ $(4.3 \mathrm{M}) \mathrm{NaCl}$. Magnesium was not required for growth. The growth $\mathrm{pH}$ range was 6.5-10.0 (optimum growth at $\mathrm{pH} 7.0-7.5)$ and the isolates grew at $35-50{ }^{\circ} \mathrm{C}$ (optimum growth at $37-40{ }^{\circ} \mathrm{C}$ ). They reduced nitrate to nitrite and anaerobic growth with arginine or nitrate did not occur. They were positive for catalase and oxidase, but did not form indole. Both strains hydrolysed aesculin, starch, and Tweens 20, 40, 60 and 80. Strain Al- $5^{\mathrm{T}}$ hydrolysed gelatin, but strain K-1 did not. Acid production from D-fructose and $\mathrm{D}$-arabinose was observed. The results of the antibiotic susceptibility and substrate utilization tests are included in the species description.

Polar lipids were extracted from the strains using a modified Bligh and Dyer extraction procedure (Kates, 1972). They were separated by TLC using a single development on silica gel in a chloroform/methanol/acetic acid/water $(85: 22.5: 10: 4$, by vol.) solvent system. In addition, two dimensional chromatography was performed by using chloroform/methanol/water ( $65: 25: 4$, by vol.) in the first dimension and chloroform/methanol/acetic acid/water $(80: 12: 15: 4$, by vol.) in the second dimension. Glycolipid spots were detected by spraying the plates with $0.5 \%(\mathrm{w} / \mathrm{v}) \alpha-$ naphthol in $50 \%$ methanol and then with $5 \% \mathrm{H}_{2} \mathrm{SO}_{4}$ in ethanol and heating them at $150{ }^{\circ} \mathrm{C}$. The polar lipid profile of strains Al $-5^{\mathrm{T}}$ and $\mathrm{K}-1$ was similar to that of Halomicrobium mukohataei DSM $12286^{\mathrm{T}}$, having phosphatidylglycerol, phosphatidylglycerophosphate methyl ester, sulfated diglycosyl diether and diglycosyl diether, but the two novel strains did not contain phosphatidylglycerosulfate.

DNA was isolated and purified by the method described by Lind \& Ursing (1986). The 16S rRNA genes of strains Al- $5^{\mathrm{T}}$ and K-1 were amplified by PCR using universal primers as described previously (Arahal et al., 1996). Multiple sequence alignments were performed using CLUSTAL W version 1.8 (Thompson et al., 1994). Phylogenetic trees were constructed on the basis of the neighbour-joining (Saitou \& Nei, 1987) and maximum-parsimony (Fitch, 1971) methods using the MEGA3 program package (Kumar et al., 2004). DNA G + C content was determined from the mid-point value $\left(T_{\mathrm{m}}\right)$ of the thermal denaturation profile (Marmur \& Doty, 1962) with a Perkin-Elmer Lambda 3B spectrophotometer at $260 \mathrm{~nm}$. DNA-DNA hybridization studies were performed by the non-radioactive method 
described by Ziemke et al. (1998). DNA was doublelabelled using DIG-11-dUTP and biotin-16-dUTP (Boehringer Mannheim). The labelling reaction was carried out using the Boehringer Mannheim nick-translation kit.

The 16S rRNA gene sequences of strains Al- $5^{\mathrm{T}}$ (1419 bp) and K-1 (1308 bp) were determined. The two sequences shared a high degree of similarity $(99.5 \%)$. Phylogenetic analysis based on $16 \mathrm{~S}$ rRNA gene similarities showed that strains $\mathrm{Al}-5^{\mathrm{T}}$ and $\mathrm{K}-1$ were closely related to Halomicrobium mukohataei DSM $12286^{\mathrm{T}}$ (similarities of 97.5 and $96.9 \%$, respectively). Phylogenetic analysis using the neighbour-joining algorithm revealed that strains $\mathrm{Al}-5^{\mathrm{T}}$ and K-1 were related to Halomicrobium mukohataei DSM $12286^{\mathrm{T}}$, forming a branch in the cluster with a bootstrap value of $100 \%$ (Fig. 1). The phylogenetic position of both strains was also confirmed in a tree generated using the maximum-parsimony algorithm (see Supplementary Fig. S1 available in IJSEM Online).

The DNA G $+\mathrm{C}$ contents of strains $\mathrm{Al}-5^{\mathrm{T}}$ and $\mathrm{K}-1$ were 52.4 and $52.9 \mathrm{~mol} \%$, respectively, as determined by the thermal denaturation method. These are lower than the values reported for members of the family Halobacteriaceae (Grant et al., 2001), but close to the value found for Halobacterium noricense DSM $15987^{\mathrm{T}} \quad(54.3 \mathrm{~mol} \%)$ (Gruber et al., 2004). DNA-DNA hybridization between the two isolates showed that isolate $\mathrm{Al}-5^{\mathrm{T}}$ had a relatedness value of $94.3 \pm 0.3 \%$ to isolate $\mathrm{K}-1$. This high relatedness value indicates that the two strains are representatives of the same species. DNA-DNA reassociation between strain $\mathrm{Al}-5^{\mathrm{T}}$ and the related strain Halomicrobium mukohataei DSM $12286^{\mathrm{T}}$ was $55.7 \pm 2.5 \%$.

On the basis of their phenotypic and chemotaxonomic characteristics, including low levels of DNA-DNA related- ness to Halomicrobium mukohataei DSM $12286^{\mathrm{T}}$, the new strains described herein are considered to represent a novel species of the genus Halomicrobium, for which the name Halomicrobium katesii sp. nov. is proposed. Table 1 shows the features that distinguish this novel species from Halomicrobium mukohataei DSM $12286^{\mathrm{T}}$.

\section{Description of Halomicrobium katesii sp. nov.}

Halomicrobium katesii (ka.tes.i.i. N.L. gen. masc. n. katesii of Kates, named in honour of Professor Morris Kates, for his contributions on halophilic micro-organisms).

Gram-negative, non-motile and short-rod-shaped (1.80$2.25 \times 2.25-2.80 \mu \mathrm{m})$. Colonies are orange, circular with an entire margin and the surface is smooth with a diameter of $2.0 \mathrm{~mm}$ on medium containing $25 \%(\mathrm{w} / \mathrm{v}) \mathrm{NaCl}$ after incubation for 5 days at $40{ }^{\circ} \mathrm{C}$. Growth occurs at 20-30\% (3.4-5.2 M) $\mathrm{NaCl}, 35-50{ }^{\circ} \mathrm{C}$ and $\mathrm{pH}$ 6.5-10.0; optimal conditions are $37-40{ }^{\circ} \mathrm{C}, \mathrm{pH} 7.0-7.5$ and $25 \%(4.3 \mathrm{M})$ $\mathrm{NaCl}$. Magnesium is not required. Reduces nitrate to nitrite and indole is not produced. Anaerobic growth with nitrate or arginine does not occur. Catalase- and oxidasepositive. Aesculin, starch and Tweens $20,40,60$ and 80 are hydrolysed. Gelatin is hydrolysed by strain $\mathrm{Al}-5^{\mathrm{T}}$, but not by strain K-1. The following substrates are utilized for growth: D-glucose, D-fructose, D-galactose, maltose, cellobiose, starch, trehalose, adonitol, glycerol, D-mannitol, Dsorbitol, acetate and pyruvate. No growth occurs on lactose, D-xylose, D-mannose, L-arabinose, raffinose, Dsalicin, L-sorbose, L-rhamnose, sucrose, dulcitol, inositol, succinate, malate, gluconate, citrate, formate, oxalate, propionate, benzoate, $\mathrm{L}$-alanine, $\mathrm{L}$-arginine, $\mathrm{L}$-aspartate, $\mathrm{L}-$ asparagine, L-cysteine, glycine, L-glutamate, L-histidine, Lleucine, L-lysine, L-methionine, L-ornithine, L-tryptophan, L-tyrosine or L-valine. Acid is produced from D-fructose

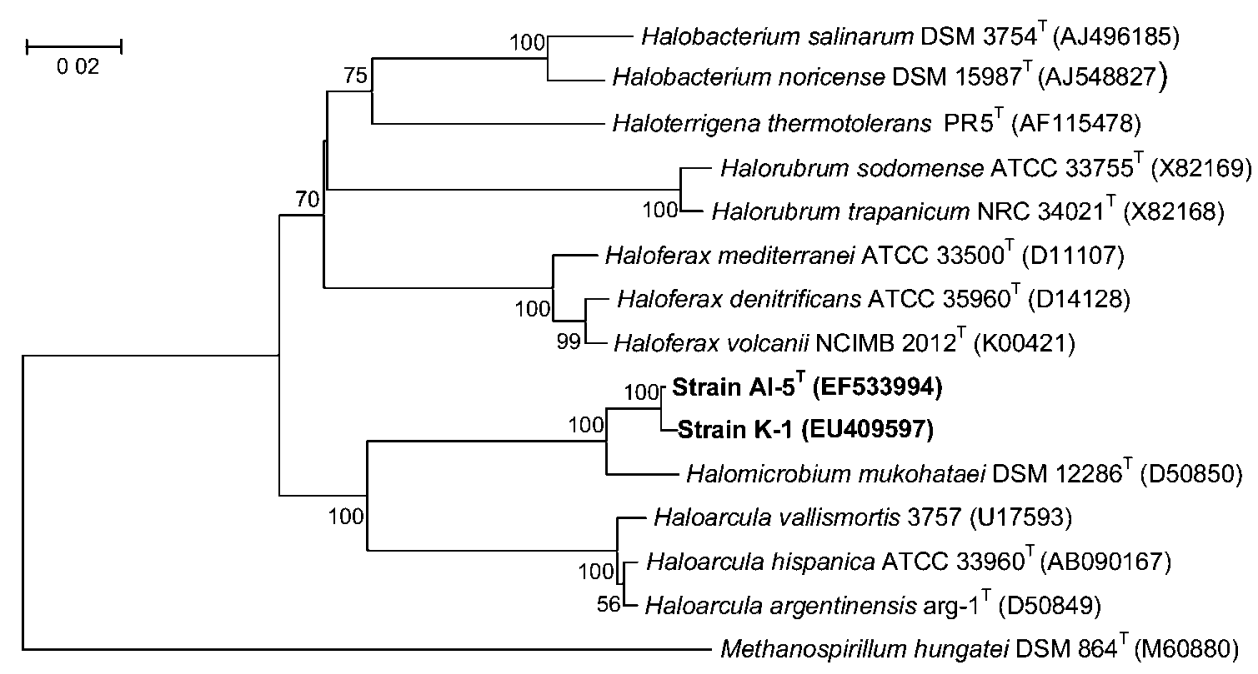

Fig. 1. Neighbour-joining phylogenetic tree based on $16 \mathrm{~S}$ rRNA gene sequences showing the position of strains $A l-5^{\top}$ and $K-1$ with respect to other species of the family Halobacteriaceae. Numbers at nodes indicate bootstrap values (based on 1000 replications). Bar, 0.02 substitutions per nucleotide position. 
Table 1. Characteristics that distinguish Halomicrobium katesii sp. nov. from Halomicrobium mukohataei DSM $12286^{\top}$

Both species utilize D-glucose, D-galactose and maltose and hydrolyse starch. +, Positive; -, negative; NR, not reported.

\begin{tabular}{|c|c|c|}
\hline Characteristic & $\begin{array}{c}\text { Halomicrobium } \\
{\text { katesii } \mathrm{Al}-5^{\mathrm{T}}}^{\text {a }}\end{array}$ & 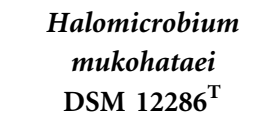 \\
\hline Pigmentation & Orange & Red-orange $^{*}$ \\
\hline Cell shape & Short rods & Short or longer rods $\dagger$ \\
\hline Size $(\mu \mathrm{m})$ & $\begin{array}{r}1.80-2.25 \times \\
2.25-2.80\end{array}$ & $1-3$ or $3.0-8.0 \times 0.5 \dagger$ \\
\hline $\begin{array}{l}\mathrm{Mg}^{2+} \text { required for } \\
\text { growth }(\mathrm{mM})\end{array}$ & 0 & $3^{*}$ \\
\hline $\mathrm{NaCl}$ range $(\mathrm{M})$ & $3.4-5.2$ & $2.5-4.5^{\star}$ \\
\hline $\mathrm{pH}$ range & $6.5-10.0$ & $6.2-8.0 \dagger$ \\
\hline Temperature range $\left({ }^{\circ} \mathrm{C}\right)$ & $35-50$ & NR \\
\hline \multicolumn{3}{|l|}{ Hydrolysis of: } \\
\hline Aesculin & + & NR \\
\hline Tween 80 & + & $-\dagger$ \\
\hline Gelatin liquefaction & + & $-\dagger$ \\
\hline \multicolumn{3}{|l|}{ Utilization of: } \\
\hline Sucrose & - & $+\dagger$ \\
\hline Glycerol & - & $+\dagger$ \\
\hline Presence of PGS $\ddagger$ & - & $+^{*}$ \\
\hline $\begin{array}{l}\text { DNA G }+ \text { C content } \\
(\mathrm{mol} \%) \S\end{array}$ & $52.4-52.9$ & $65^{*}$ \\
\hline
\end{tabular}

${ }^{\star}$ Data from Ihara et al. (1997).

$\dagger$ Data from Oren et al. (2002).

¥PGS, Phosphatidylglycerosulfate.

§Determined by the $T_{\mathrm{m}}$ method.

and D-arabinose. Cells are resistant to penicillin $\mathrm{G}(10 \mathrm{U})$, chloramphenicol (30 mg), kanamycin (30 mg), ampicillin (10 mg), tetracycline (30 mg), erythromycin (15 mg), streptomycin $(10 \mathrm{mg})$, polymyxin B (300 U), neomycin (30 $\mathrm{mg})$, gentamicin (10 $\mathrm{mg}$ ) and carbenicillin $(50 \mathrm{mg})$, but susceptible to bacitracin (10 U) and novobiocin (30 mg). The polar lipids present are phosphatidylglycerol, phosphatidylglycerophosphate methyl ester, sulfated diglycosyl diether and diglycosyl diether. Phosphatidylglycerosulfate is absent. DNA $\mathrm{G}+\mathrm{C}$ content is $52.4-$ $52.9 \mathrm{~mol} \%\left(T_{\mathrm{m}}\right)$.

The type strain, Al-5 $5^{\mathrm{T}}\left(=\mathrm{CECT} 7257^{\mathrm{T}}=\mathrm{DSM} 19301^{\mathrm{T}}\right)$, was isolated from Lake Tebenquiche in the Atacama Saltern, Chile. Strain K-1, isolated from water samples collected from Ezzemoul sabkha, Algeria, is a reference strain.

\section{Acknowledgements}

We are grateful to Dr Jean Euzéby for etymological advice. This study was supported by grants from the Junta de Andalucía (project CVI190), Spain and with support from the Algerian Ministry of Education.

\section{References}

Arahal, D. R., Dewhirst, F. E., Paster, B. J., Volcani, B. E. \& Ventosa, A. (1996). Phylogenetic analysis of some extremely halophilic archaea isolated from Dead Sea water, determined on the basis of their 16S rRNA sequences. Appl Environ Microbiol 62, 3779-3786.

Bardavid, R. E., Mana, L. \& Oren, A. (2007). Haloplanus natans gen. nov., sp. nov., an extremely halophilic, gas-vacuolate archaeon isolated from Dead Sea-Red Sea water mixtures in experimental outdoor ponds. Int J Syst Evol Microbiol 57, 780-783.

Burns, D. G., Janssen, P. H., Itoh, T., Kamekura, M., Li, Z., Jensen, G., Rodriguez-Valera, F., Bolhuis, H. \& Dyall-Smith, M. L. (2007). Haloquadratum walsbyi gen. nov., sp. nov., the square haloarchaeon of Walsby, isolated from saltern crystallizers in Australia and Spain. Int J Syst Evol Microbiol 57, 387-392.

Castillo, A. M., Gutiérrez, M. C., Kamekura, M., Ma, Y., Cowan, D. A., Jones, B. E., Grant, W. D. \& Ventosa, A. (2006a). Halovivax asiaticus gen. nov., sp. nov., a novel extremely halophilic archaeon isolated from Inner Mongolia, China. Int J Syst Evol Microbiol 56, 765-770.

Castillo, A. M., Gutiérrez, M. C., Kamekura, M., Xue, Y., Ma, Y., Cowan, D. A., Jones, B. E., Grant, W. D. \& Ventosa, A. (2006b). Halostagnicola larsenii gen. nov., sp. nov., an extremely halophilic archaeon from a saline lake in Inner Mongolia, China. Int J Syst Evol Microbiol 56, 1519-1524.

Dussault, H. P. (1955). An improved technique for staining red halophilic bacteria. J Bacteriol 70, 484-485.

Fitch, W. M. (1971). Toward defining the course of evolution: minimum change for a specific tree topology. Syst Zool 20, 406-416.

Gerhardt, P., Murray, R. G. E., Wood, W. A. \& Krieg, N. R. (editors) (1994). Methods for General and Molecular Bacteriology. Washington, DC: American Society for Microbiology.

González, C., Gutiérrez, C. \& Ramirez, C. (1978). Halobacterium vallismortis $\mathrm{sp}$. nov., an amylolytic and carbohydrate-metabolizing, extremely halophilic bacterium. Can J Microbiol 24, 710-715.

Grant, W. D. (2001a). Genus I. Halobacterium Elazari-Volcani 1957, $207^{\mathrm{AL}}$ emend. Larsen and Grant 1989, 2222. In Bergey's Manual of Systematic Bacteriology, 2nd edn, vol. 1, pp. 301-305. Edited by D. R. Boone, R. W. Castenholz \& G. M. Garrity. New York: SpringerVerlag.

Grant, W. D. (2001b). Genus IV. Halococcus Schoop 1935a, $817^{\mathrm{AL}}$. In Bergey's Manual of Systematic Bacteriology, 2nd edn, vol. 1, pp. 311314. Edited by D. R. Boone, R. W. Castenholz \& G. M. Garrity. New York: Springer-Verlag.

Grant, W. D., Kamekura, M., McGenity, T. J. \& Ventosa, A. (2001). Order I. Halobacteriales. In Bergey's Manual of Systematic Bacteriology, 2nd edn, vol. 1, pp. 294-334. Edited by D. R. Boone, R. W. Castenholz \& G. M. Garrity. New York: Springer.

Gruber, C., Legat, A., Ptaffenhuemer, M., Radax, C., Weidler, G., Busse, H.-J. \& Stan-Lotter, H. (2004). Halobacterium noricense sp. nov., an archaeal isolate from a bore core of an alpine Permian salt deposit, classification of Halobacterium sp. NRC-1 as a strain of $H$. salinarum and emended description of H. salinarum. Extremophiles $\mathbf{8}$, 431-439.

Gutiérrez, C. \& González, C. (1972). Methods for simultaneous detection of proteinase and esterase activities in extremely halophilic bacteria. Appl Microbiol 24, 516-517.

Gutiérrez, M. C., Castillo, A. M., Kamekura, M., Xue, Y., Ma, Y., Cowan, D. A., Jones, B. E., Grant, W. D. \& Ventosa, A. (2007). Halopiger xanaduensis gen. nov., sp., nov., an extremely halophilic archaeon isolated from saline Lake Shangmatala in Inner Mongolia, China. Int J Syst Evol Microbiol 57, 1402-1407. 
Hezayen, F. F., Tindall, B. J., Steinbüchel, A. \& Rehm, B. H. A. (2002). Characterization of a novel halophilic archaeon, Halobiforma haloterrestris gen. nov., sp. nov., and transfer of Natronobacterium nitratireducens to Halobiforma nitratireducens comb. nov. Int J Syst Evol Microbiol 52, 2271-2280.

Ihara, K., Watanabe, S. \& Tamura, T. (1997). Haloarcula argentinensis sp. nov. and Haloarcula mukohataei sp. nov., two new extremely halophilic archaea collected in Argentina. Int J Syst Bacteriol 47, 73-77.

Itoh, T., Yamaguchi, T., Zhou, P. \& Takashina, T. (2005). Natronolimnobius baerhuensis gen. nov., sp. nov. and Natronolimnobius innermongolicus sp. nov., novel haloalkaliphilic archaea isolated from soda lakes in Inner Mongolia, China. Extremophiles 9, 111-116.

Kamekura, M. \& Dyall-Smith, M. L. (1995). Taxonomy of the family Halobacteriaceae and the description of two new genera Halorubrobacterium and Natrialba. J Gen Appl Microbiol 41, 333-350.

Kamekura, M., Dyall-Smith, M. L., Upasani, V., Ventosa, A. \& Kates, M. (1997). Diversity of alkaliphilic halobacteria: proposals for transfer of Natronobacterium vacuolatum, Natronobacterium magadii, and Natronobacterium pharaonis to Halorubrum, Natrialba, and Natronomonas gen. nov., respectively, as Halorubrum vacuolatum comb. nov., Natrialba magadii comb. nov., and Natronomonas pharaonis comb. nov., respectively. Int J Syst Bacteriol 47, 853-857.

Kates, M. (1972). Techniques of Lipidology. New York: Elsevier.

Kumar, S., Tamura, K. \& Nei, M. (2004). MEGA 3: integrated software for molecular evolutionary genetics analysis and sequence alignment. Brief Bioinform 5, 150-163.

Lind, E. \& Ursing, J. (1986). Clinical strains of Enterobacter agglomerans (synonyms: Erwinia herbicola, Erwinia milletiae) identified by DNA-DNA-hybridization. Acta Pathol Microbiol Immunol Scand $[B]$ 94, 205-213.

Lizama, C., Monteoliva-Sanchez, M., Prado, B., RamosCormenzana, A., Weckesser, J. \& Campos, V. (2001). Taxonomic study of extreme halophilic archaea isolated from the "Salar de Atacama", Chile. Syst Appl Microbiol 24, 464-474.

Marmur, J. \& Doty, P. (1962). Determination of the base composition of deoxyribonucleic acid from its thermal denaturation temperature. $J$ Mol Biol 5, 109-118.

McGenity, T. J. \& Grant, W. D. (1995). Transfer of Halobacterium saccharovorum, Halobacterium sodomense, Halobacterium trapanicum NRC 34041 and Halobacterium lacusprofundi to the genus Halorubrum gen. nov., as Halorubrum saccharovorum comb. nov., Halorubrum sodomense comb. nov., Halorubrum trapanicum comb. nov. and Halorubrum lacusprofundi comb. nov. Syst Appl Microbiol 18, 237-243.

McGenity, T. J., Gemmell, R. T. \& Grant, W. D. (1998). Proposal of a new halobacterial genus Natrinema gen. nov., with two species Natrinema pellirubrum nom. nov. and Natrinema pallidum nom. nov. Int J Syst Bacteriol 48, 1187-1196.

Montalvo-Rodriguez, R., Vreeland, R. H., Oren, A., Kessel, M., Betancourt, C. \& López-Garriga, J. (1998). Halogeometricum borinquense gen. nov., sp. nov., a novel halophilic archaeon from Puerto Rico. Int J Syst Bacteriol 48, 1305-1312.

Oren, A., Gurevich, P., Gemmell, R. T. \& Teske, A. (1995). Halobaculum gomorrense gen. nov., sp. nov., a novel extremely halophilic archaeon from the Dead Sea. Int J Syst Bacteriol 45, 747-754.
Oren, A., Ventosa, A. \& Grant, W. D. (1997). Proposed minimal standards for description of new taxa in the order Halobacteriales. Int J Syst Bacteriol 47, 233-238.

Oren, A., Elevi, R., Watanabe, S., Ihara, K. \& Corcelli, A. (2002). Halomicrobium mukohataei gen. nov., comb. nov., and emended description of Halomicrobium mukohataei. Int J Syst Evol Microbiol 52, 1831-1835.

Saitou, N. \& Nei, M. (1987). The neighbor-joining method; a new method for reconstructing phylogenetic trees. Mol Biol Evol 4, 406425.

Savage, K. N., Krumholz, L. R., Oren, A. \& Elshahed, M. S. (2007), Haladaptatus paucihalophilus gen. nov., sp. nov., a halophilic archaeon isolated from a low-salt, sulfide-rich spring. Int J Syst Evol Microbiol 57, 19-24.

Smibert, R. M. \& Krieg, N. R. (1981). General characterization. In Manual of Methods for General Microbiology, pp. 409-443. Edited by P. Gerhardt, R. G. E. Murray, R. N. Costilow, E. W. Nester, W. A. Wood, N. R. Krieg \& G. B. Phillips. Washington DC: American Society for Microbiology.

Subov, N. N. (1931). Oceanographical Tables. Moscow: USSR Oceanographic Institute Hydrometeorological Commission.

Thompson, J. D., Higgins, D. G. \& Gibson, T. J. (1994). ClusTAL W: improving the sensitivity of progressive multiple sequence alignment through sequence weighting, position-specific gap penalties and weight matrix choice. Nucleic Acids Res 22, 4673-4680.

Tindall, B. J., Ross, H. N. M. \& Grant, W. D. (1984). Natronobacterium gen. nov. and Natronococcus gen. nov., two new genera of haloalkaliphilic archaebacteria. Syst Appl Microbiol 5, 41-57.

Torreblanca, M., Rodríguez-Valera, F., Juez, G., Ventosa, A., Kamekura, M. \& Kates, M. (1986). Classification of non-alkaliphilic halobacteria based on numerical taxonomy and polar lipid composition, and description of Haloarcula gen. nov. and Haloferax gen. nov. Syst Appl Microbiol 8, 89-99.

Ventosa, A., Gutiérrez, M. C., Kamekura, M. \& Dyall-Smith, M. L. (1999). Proposal to transfer Halococcus turkmenicus, Halobacterium trapanicum JCM 9743 and strain GSL-11 to Haloterrigena turkmenica gen. nov., comb. nov. Int J Syst Bacteriol 49, 131-136.

Vreeland, R. H., Straight, S., Krammes, J., Dougherty, K., Rosenzweig, W. D. \& Kamekura, M. (2002). Halosimplex carlsbadense gen. nov., sp. nov., a unique halophilic archaeon, with three $16 \mathrm{~S}$ rRNA genes, that grows only in defined medium with glycerol and acetate or pyruvate. Extremophiles 6, 445-452.

Wainø, M., Tindall, B. J. \& Ingvorsen, K. (2000). Halorhabdus utahensis gen. nov., sp. nov., an aerobic, extremely halophilic member of the Archaea from Great Salt Lake, Utah. Int J Syst Evol Microbiol 50, 183-190.

Xu, Y., Zhou, P. \& Tian, X. (1999). Characterization of two novel haloalkaliphilic archaea, Natronorubrum bangense gen. nov., sp. nov. and Natronorubrum tibetense gen. nov., sp. nov. Int J Syst Bacteriol 49, 261-266.

Xue, Y., Fan, H., Ventosa, A., Grant, W. D., Jones, B. E., Cowan, D. A. \& Ma, Y. (2005). Halalkalicoccus tibetensis gen. nov., sp. nov., representing a novel genus of haloalkaliphilic archaea. Int J Syst Evol Microbiol 55, 2501-2505.

Ziemke, F., Höfle, M. G., Lalucat, J. \& Rosselló-Mora, R. (1998). Reclassification of Shewanella putrefaciens Owen's genomic group II as Shewanella baltica sp. nov. Int J Syst Bacteriol 48, 179-186. 